\title{
Laparoscopic ablative techniques
}

\author{
Tommaso Silvestri, Bernardino de Concilio, Guglielmo Zeccolini, Antonio Celia \\ Urology Unit, “San Bassiano" Hospital, ULSS7 Pedemontana, Bassano del Grappa, VI 36061, Italy.
}

Correspondence to: Dr. Tommaso Silvestri, Urology Unit, "San Bassiano" Hospital, ULSS7 Pedemontana, Bassano del Grappa, VI 36061, Italy. E-mail: tommaso.silve@gmail.com

How to cite this article: Silvestri T, de Concilio B, Zeccolini G, Celia A. Laparoscopic ablative techniques. Mini-invasive Surg 2019;3:5. http://dx.doi.org/10.20517/2574-1225.2018.67

Received: 30 Nov 2018 First Decision: 30 Nov 2018 Revised: 28 Jan 2019 Accepted: 11 Feb 2019 Published: 4 Mar 2019

Science Editor: Richard Lawrence John Naspro Copy Editor: Cui Yu Production Editor: Huan-Liang Wu

\begin{abstract}
Ablative techniques (AT) offer a combination of nephron-sparing and minimally invasive approaches. AT include different options and cryoablation (CA) and radiofrequency ablation (RFA) have been relatively safe and traditionally can be either performed laparoscopically or percutaneously. CA and RFA have emerged as a leading option for renal ablation, and compared with surgical techniques they offer benefits in preserving renal function with fewer complications, shorter hospitalization times, and allow for quicker convalescence. A mature dataset exists at this time, with intermediate and long-term follow up data available. Generally, laparoscopic access was the first technique used in the past, and typically for anterior and lateral mass. Afterwards, with the improvements in imaging and percutaneous techniques, laparoscopic approaches are progressively decreased and currently limited in few lesions and in relation with the surgeon's and center's experience. Nevertheless, laparoscopic CA and RFA could be useful techniques and currently, recommendations as a first-line therapy are made at this time in limited populations, including elderly patients, patients with multiple comorbidities, and those with imperative indications of a nephron sparing surgery. As more data emerge on oncologic efficacy, and technical experience continue to improve, the application of AT will likely be extended in future treatment guidelines and laparoscopic approaches will be a valid option in the era of tailored therapy.
\end{abstract}

Keywords: Laparoscopic kidney cryoablation, small renal masses, laparoscopic ablative techniques

\section{INTRODUCTION}

Although surgery remains the definitive recommended treatment of small renal masses (SRM), ablative techniques (AT) have emerged recently, particularly for tumors $<4 \mathrm{~cm}$, and for those patients who cannot undergo surgery or with imperative indications of nephron sparing surgery (NSS). AT included: cryoablation (CA), radiofrequency ablation (RFA), microwave ablation, laser thermal ablation, and highintensity focused ultrasound. Historically CA and RFA have been introduced first worldwide, and recently

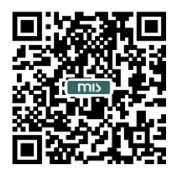


longer-term outcomes for these techniques have become available ${ }^{[1-5]}$. They can be performed either laparoscopically or percutaneously with good results in spite of higher reported recurrence and retreatment rates when compared to partial nephrectomy $(\mathrm{PN})^{[6,7]}$.

Historically laparoscopic cryoablation (LCA) has been the most popular approach for performing renal $\mathrm{CA}^{[8,9]}$. Conversely, laparoscopic techniques for RFA have been used less in favor of percutaneous RFA, successfully performed under ultrasound, CT, or MRI guidance ${ }^{[10]}$.

Anyway, over the years, also LCA have seen gradual decrease in utilization as image-guided techniques have improved greatly and currently American Urological Association (AUA) guidelines recommend also percutaneous cryoablation (PCA) as the best possible choice ${ }^{[11,12]}$.

In this review, we focused on LCA in relation to its major diffusion and availability worldwide, particularly with SRMs with diameter $>3 \mathrm{~cm}$ in comparison to RFA ablation.

\section{CRYOBIOLOGY AND AVAILABLE SYSTEMS}

The principles of cryotherapy, including the mechanism of cell injury and cell death, have been well studied $^{[13-15]}$. The main mechanism of cryo-toxicity is the induction of coagulative necrosis in targeted areas. The key factors involved in freezing injury include direct mechanical shock, osmotic shock, and cellular hypoxia. Mechanism of action includes protein denaturation via dehydration, transfer of water from the intracellular space to the extracellular space, rupture of cell membranes from ice crystal expansion, a toxic concentration of cellular constituents, thermal shock from rapid super-cooling, slow thawing, vascular stasis, and increased apoptosis. The delayed or indirect destructive effects of cryotherapy continue primarily because of vasculature disruption, resulting in tissue hypoxia and vascular thrombosis ${ }^{[16]}$.

Stephenson started the first cases of LCA in a canine model and the transition to the second and the third generation of cryoprobes have permitted the use of ultra-thin probes, leading to rapid diffusion of the technique $^{[17]}$.

Currently, the available cryogenic systems, that use pressurized argon gas as the source of freezing, are: the SeedNet ${ }^{\circledR}$ System, the Visual-ICE ${ }^{\oplus}$ System (Galil Medical Inc., BTG, UK) and the CRYOcare ${ }^{\mathrm{TM}}$ System (Endocare Inc., USA). These systems are used to create a conformal freezing pattern up to 25-17 gauge (2.4-1.47 mm) cryoprobe.

\section{ADVANTAGES AND DISADVANTAGES OF LCA}

Currently, considerations such as tumor location and complexity as well as patient morbidity must be made when selecting a modality and approach. With initial experience, LCA was utilized primarily for anteriorly and laterally located tumors, and PCA was the method of choice for posterior tumors ${ }^{[18]}$.

The main advantages of LCA are ${ }^{[19]}$ : (1) placement of probes under direct visualization; (2) real-time USguided placement of probes and monitoring of procedure (freezing and tissue viability); (3) easier treatment of anterior or hilar tumors; (4) major ability to displace colon or other organs or nearby structures whenever necessary for a safer ablation.

However, increasing experience during the last two decades has demonstrated that although technically challenging, also anterior tumors can be successfully treated via the percutaneous route, often with adjunctive displacement maneuvers ${ }^{[20]}$. 
Hence, the main disadvantages of LCA are ${ }^{[21]}$ : (1) general anesthesia is required (it is not an outpatient procedure); (2) a higher rate of complication in comparison to PCA; (3) less rate of pain control and worst cosmetic in comparison to PCA; (4) higher cost rate in comparison to PCA.

\section{PATIENT SELECTION AND INDICATION FOR LCA}

The indications for LCA procedure are the same of all ablative techniques and limited to patients with contraindications to surgical extirpative therapy for comorbidities, advanced age, imperative indications for NSS or have a strong preference for nonsurgical management ${ }^{[1]}$.

Currently, the 2017 AUA guidelines recommend consideration of ablation as an alternative to PN for cT1a renal lesions less than $3 \mathrm{~cm}$ in size ${ }^{[12]}$. Otherwise, the European Association of Urology guidelines do not recommend an upper limit of diameter ${ }^{[1]}$. Today there are data supporting CA for $\mathrm{cT} 1 \mathrm{~b}$ lesions, but in view of higher recurrence rate and complications should be reserved for patients with imperative indications ${ }^{[22]}$.

The location of the mass is a major factor in determining if the mass should be ablated laparoscopically or percutaneously, but the most important factor is the surgeons' experience.

\section{PROCEDURE AND TECHNIQUES}

A transperitoneal approach is generally used for anterior and anteromedial tumors, whereas a retroperitoneal approach permits access to posterior and posterolateral tumors ${ }^{[23,24]}$.

Effective cryosurgical tissue injury depends on: (1) excellent monitoring of the process; (2) fast cooling to a lethal temperature; (3) slow thawing; (4) repetition of the freeze-thaw cycle (2 times); (5) freeze cycle length of 8-10 $\mathrm{min}$ is commonplace in literature; (6) thaw cycle at least 5-8 min.

Critical factors of the procedure are: (1) placement of the cryoneedles; (2) reach and center a lethal temperature in the central part of the lesion with an ice ball margin of at least $5 \mathrm{~mm}$ to avoid a residual or an untreated tumor ${ }^{[25]}$; (3) iceball imaging as mentioned above.

Key factors to obtain specific success of LCA: (1) take your time to make a better exposure of the renal lesion: the real key is finding the better position for the cryoneedles; (2) triangle disposition of the cryoneedles by putting the different probes at least $10 \mathrm{~mm}$ of distance each other; (3) the using of hemostatic agents to prevent or treat bleeding; (4) high experience of the surgeon in NSS: in some rare case, it could be necessary to put sutures.

The number and size of the cryoprobes placed depends on the size and configuration of the mass. Generally, one probe is needed for each centimeter of tumor diameter to be treated. Recently, the use of multiple smaller probe has increased the variety and size of tumors that can be treated. When mobilization of the kidney is feasible, US probes are placed on the contralateral side of the kidney for visualization. Attention should be reserved for relative warming of the ablation zone by large central vessels: the thermal sink effect might be a limit to achieve the lethal temperature.

\section{Laparoscopic cryoablation}

Pneumoperitoneum and trocars placement

General anesthesia is required. The patient is placed in a standard flank position. Pneumoperitoneum is usually achieved in two ways: using the open Hasson technique or by placing a Veress needle in the umbilicus of the patient who have not had previous abdominal surgery or in the upper quadrant (left 


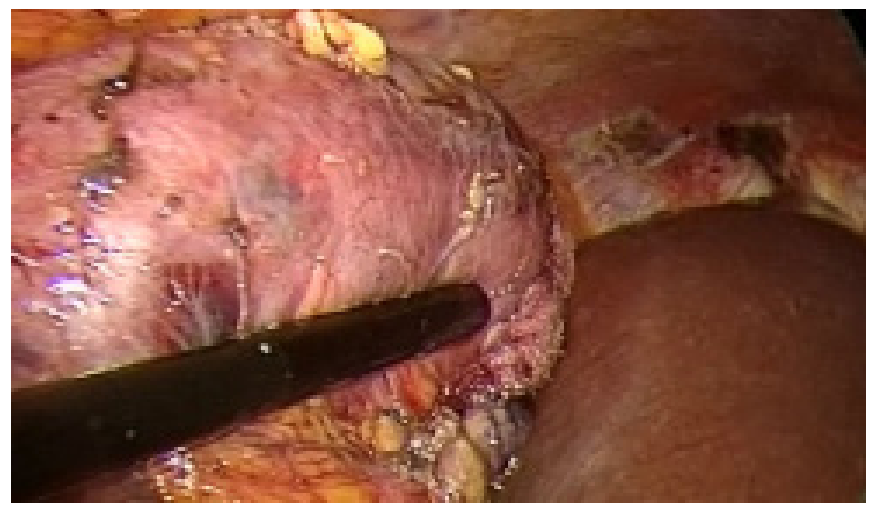

Figure 1. Ultrasound evaluation of the lesion

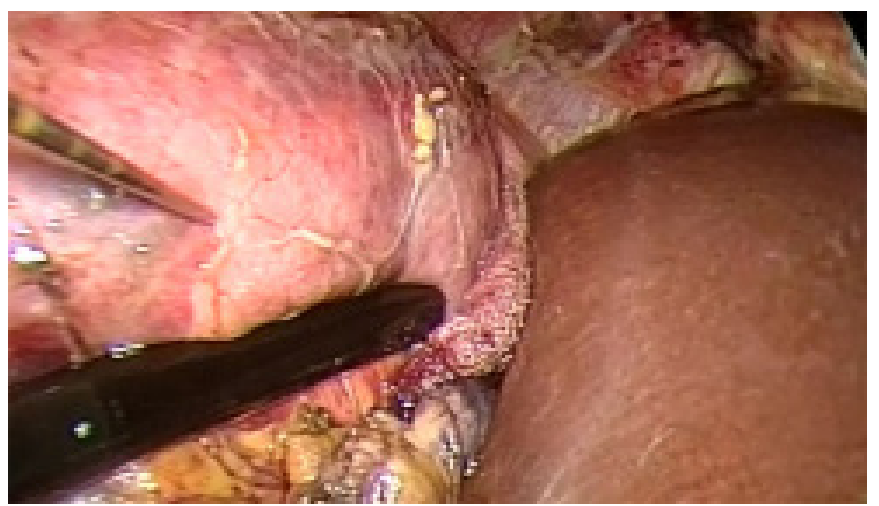

Figure 2. Under ultrasound evaluation a 1.5 cryoprobe is inserted into the mass

or right). Therefore, at least 3 trocars are placed as for laparoscopic nephrectomy. An extra $5 \mathrm{~mm}$ port is inserted as per requirement for suction or retraction.

\section{Renal dissection and US}

Visceral rotation and reflection of the colon is performed, with a gently kidney mobilization and exposition. Generally, the fat overlying the lesion should be removed, and the tumor region should be carefully dissected. Intraoperative US is performed through the $12-\mathrm{mm}$ trocar. The renal blood vessels are carefully dissected and secured using vessel-loop. Therefore, a Tru-Cut needle biopsy is performed.

\section{Cryoprobes placement}

Under US evaluation a 1.5-1.7 $\mathrm{mm}$ cryoprobe is inserted into the mass transabdominally through a skin puncture and placed into the lesion. The probe is anchored by freezing the tumor 1-2 $\mathrm{mm}$ from the probe [Figures 1 and 2]. Generally, a triangulation of one or two additional probes around the first probe could be performed in relation to the size of the lesion. The "killing zone" temperature must be $-20{ }^{\circ} \mathrm{C}$ or below.

CA cycles are performed as usual, monitored by the US [Figure 3]. At the end of the second cycles the needles are gently removed [Figure 4] and hemostatic agents such as fibrin glue (FloSeal - Baxter, Illinois, USA) is then applied to the site. The Gerota's fascia is closed and a non-suction drain is put into the peritoneal cavity. All ports are closed in the usual fashion.

\section{DISCUSSION}

CA and RFA could be an available treatment option for SRMs in selected patients. Quality of the available data and lack of level I evidence do not allow definitive conclusions regarding morbidity and oncological 


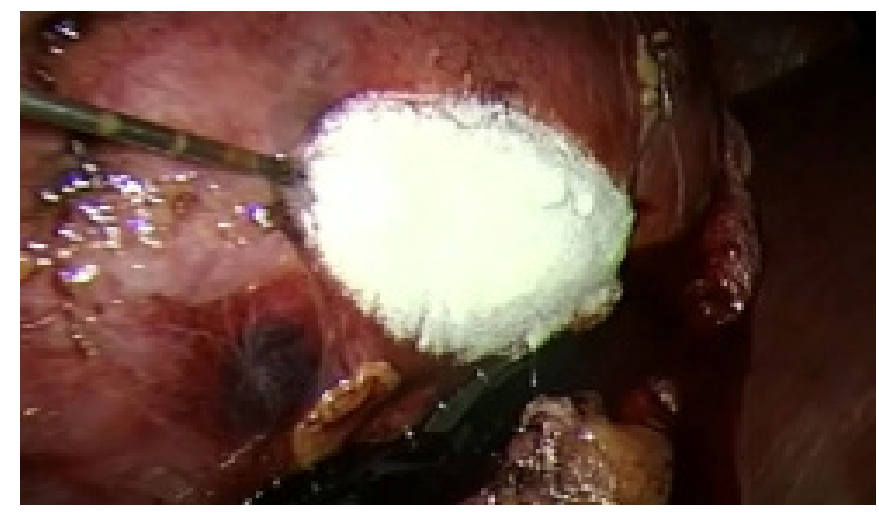

Figure 3. First freezing cycle

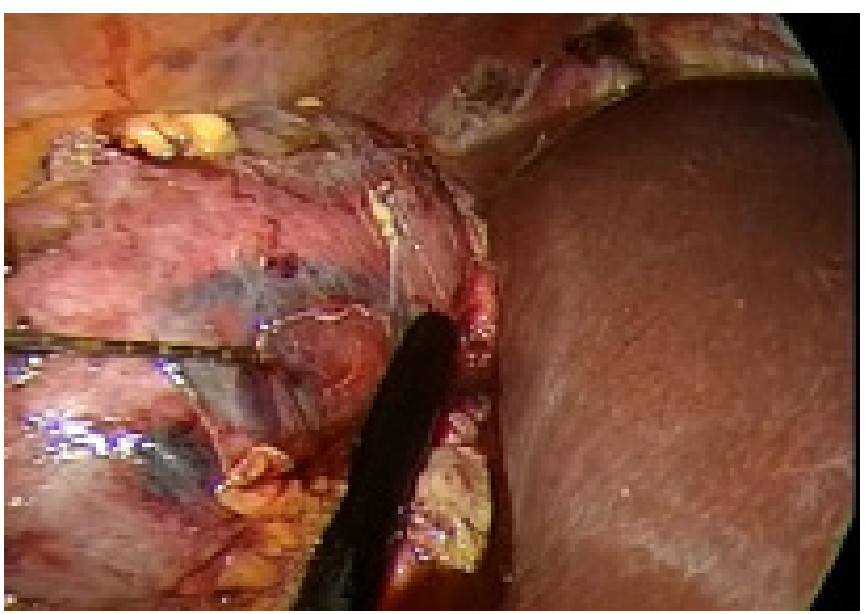

Figure 4. Under ultrasound evaluation the needle is carefully removed

outcomes of CA and RFA. Generally, low-quality studies suggest a higher local recurrence rate for thermal ablation therapies compared to PN. Nevertheless, in currently comparative series no significant differences were reported for OS, CSS, or RFS between RFA and $\mathrm{CA}^{[1]}$. Considering PN as a comparator, recently a meta-analysis reported similar complication rates and postoperative functional outcomes between RFA and $\mathrm{PN}^{[26]}$. The local tumor recurrence rate was higher in the RFA group than in the PN group but there was no difference regarding the occurrence of distant metastasis. Although the majority of series are retrospective and with different follow-ups, recent studies with a long-term follow-up showed that no statistical difference was found in the 5-year OS, CCS, DFS, and local RFS of RCC patients between RFA treatment and PN treatment $[\text { Table } 1]^{[27]}$. Johnson et al. ${ }^{[28]}$ presented data of SRMs with a diameter less than $3 \mathrm{~cm}$ with a median follow up of more than 6 years and a subgroup of patients with a minimum 10-year follow up with imaging. The 6-year disease-free recurrence rate of $89 \%$ is consistent with the prior published data. This data could suggest that for lesions less than $3 \mathrm{~cm}$ RFA oncologic outcomes were similar to efficacy rates of extirpative surgery ${ }^{[28]}$. Regarding CA different studies compared open, laparoscopic or robotic PN with PCA or LCA [Table 2]. Oncological outcomes were mixed, not all studies reported all outcomes listed, and some were small and included benign tumors. Globally no study showed an oncological benefit for cryoablation over PN.

Overall, studies comparing renal function before and after CA and PN suggest a degree of functional decline following CA similar to PN. However, in most cases, this is not clinically significant because baseline characteristics of lesions, function and the patient's comorbidities were different. No significant difference 
Table 1. Contemporary comparative series comparing radiofrequency with partial nephrectomy and/or radical nephrectomy with oncological outcomes

\begin{tabular}{|c|c|c|c|c|c|c|c|}
\hline Author & Year & End point & Therapy & $\begin{array}{l}\text { Number of } \\
\text { patients }\end{array}$ & $\begin{array}{l}\text { Study } \\
\text { design }\end{array}$ & $\begin{array}{l}\text { Follow up } \\
\text { (months) }\end{array}$ & Outcomes \\
\hline Arnoux et al. ${ }^{[43]}$ & 2013 & $\begin{array}{l}\text { Survival, recurrence, } \\
\text { complications }\end{array}$ & $\begin{array}{l}\text { RFA } \\
\text { PN }\end{array}$ & $\begin{array}{l}36 \\
14\end{array}$ & Prospective & $\begin{array}{l}22 \\
22\end{array}$ & $\begin{array}{l}\text { No recurrences in RFA and } \\
\text { PN } \\
\text { No other oncological } \\
\text { outcomes }\end{array}$ \\
\hline Bensalah et al.. ${ }^{[4]]}$ & 2007 & $\begin{array}{l}\text { Survival, recurrence, } \\
\text { complications }\end{array}$ & $\begin{array}{l}\text { RFA } \\
\text { PN }\end{array}$ & $\begin{array}{l}46 \\
56\end{array}$ & Retrospective & Mean 15 & $97 \%$ RFS, $100 \%$ CSS \\
\hline Bird et $a l^{[45]}$ & 2009 & $\begin{array}{l}\text { Survival, recurrence, } \\
\text { complications, renal } \\
\text { function }\end{array}$ & $\begin{array}{l}\text { RFA } \\
\text { PN }\end{array}$ & $\begin{array}{l}36 \\
33\end{array}$ & Retrospective & $\begin{array}{l}12 \\
27\end{array}$ & $\begin{array}{l}\text { No recurrences } \\
\text { No deaths }\end{array}$ \\
\hline Chang et al. ${ }^{[46]}$ & 2015 & $\begin{array}{l}\text { Survival, recurrence, } \\
\text { complications, renal } \\
\text { function }\end{array}$ & $\begin{array}{l}\text { RFA } \\
\text { PN }\end{array}$ & $\begin{array}{l}53 \\
53\end{array}$ & Retrospective & $\begin{array}{l}68 \\
69\end{array}$ & $\begin{array}{l}\text { No recurrences } \\
\text { No deaths }\end{array}$ \\
\hline Chang et al. ${ }^{[47]}$ & 2015 & $\begin{array}{l}\text { Survival, recurrence, } \\
\text { complications, renal } \\
\text { function }\end{array}$ & $\begin{array}{l}\text { RFA } \\
\text { PN }\end{array}$ & $\begin{array}{l}64 \\
57\end{array}$ & Retrospective & $\begin{array}{l}66 \\
70 \\
5 \text {-year } \\
\text { outcome }\end{array}$ & $\begin{array}{l}85.5 \%, 92.6 \%, 81.0 \% \\
\text { (OS, CSS, DFS) } \\
96.6 \%, 96.6 \%, 89.7 \% \\
(\text { OS, CSS, DFS) }\end{array}$ \\
\hline Ji et $a{ }^{[48]}$ & 2016 & $\begin{array}{l}\text { Recurrence, } \\
\text { complications }\end{array}$ & $\begin{array}{l}\text { RFA } \\
\text { PN }\end{array}$ & $\begin{array}{l}105 \\
74\end{array}$ & Retrospective & $\begin{array}{l}78 \\
82 \\
5 \text {-year } \\
\text { outcome }\end{array}$ & $\begin{array}{l}93.3 \%, 98.0 \%, 97.1 \% \\
\text { (OS, CSS, DFS) } \\
94.6 \%, 98.5 \%, 97.3 \% \\
(\text { OS, CSS, DFS) }\end{array}$ \\
\hline Kimet $a .^{[49]}$ & 2015 & $\begin{array}{l}\text { Survival, recurrence, } \\
\text { complications, } \\
\text { renal function }\end{array}$ & $\begin{array}{l}\text { RFA } \\
\text { PN }\end{array}$ & $\begin{array}{l}27 \\
27\end{array}$ & Retrospective & $\begin{array}{l}17 \\
11\end{array}$ & $\begin{array}{l}1 \text { recurrence } \\
2 \text { recurrence }\end{array}$ \\
\hline Liu et $\left.a\right|^{[50]}$ & 2017 & $\begin{array}{l}\text { Survival, recurrence, } \\
\text { complications, } \\
\text { renal function }\end{array}$ & $\begin{array}{l}\text { RFA } \\
\text { PN }\end{array}$ & $\begin{array}{l}93 \\
120\end{array}$ & $\begin{array}{l}\text { Prospective } \\
\text { database }\end{array}$ & 78 & $\begin{array}{l}84.9 \%, 82.8 \% \text { (OS, DFS) } \\
88.3 \%, 88.8 \% \text { (OS, DFS) } \\
\text { Differences > in lesions } \\
>4 \mathrm{~cm}\end{array}$ \\
\hline Lucas et al. ${ }^{[51]}$ & 2008 & $\begin{array}{l}\text { Recurrence, } \\
\text { renal function }\end{array}$ & $\begin{array}{l}\text { RFA } \\
\text { PN } \\
\text { RN }\end{array}$ & $\begin{array}{l}86 \\
85 \\
71\end{array}$ & Retrospective & $\begin{array}{l}40 \\
44 \\
26\end{array}$ & $\begin{array}{l}6 \text { recurrence } \\
2 \text { recurrence } \\
0 \text { recurrence }\end{array}$ \\
\hline Olweny et al. ${ }^{[52]}$ & 2012 & Recurrence & $\begin{array}{l}\text { RFA } \\
\text { PN }\end{array}$ & $\begin{array}{l}37 \\
37\end{array}$ & Prospective & $\begin{array}{l}78 \\
73 \\
5 \text {-year }\end{array}$ & $\begin{array}{l}97.2 \%, 89.2 \%, 97 \%, 91.7 \% \\
\text { (OS, DFS, CSS, local RFS) } \\
100 \%, 89.2 \%, 100 \%, 94.6 \% \\
\text { (OS, DFS, CSS, local RFS) }\end{array}$ \\
\hline $\begin{array}{l}\text { Pantelidou et } \\
\text { al. }{ }^{[53]}\end{array}$ & 2016 & Recurrence & $\begin{array}{l}\text { RFA } \\
\text { PN (robotic) }\end{array}$ & $\begin{array}{l}63 \\
63\end{array}$ & Retrospective & $\begin{array}{l}48 \\
18\end{array}$ & $\begin{array}{l}6 \text { Local recurrence, } 3 \text { Met } \\
1 \text { Local Recurrence, } 1 \text { Met } \\
\text { DFS was not significantly } \\
\text { different between the two } \\
\text { groups }(\mathrm{HR}=0.84,95 \% \mathrm{Cl} \text { : } \\
0.19-3.4 ; P=0.80\end{array}$ \\
\hline Raman et al. ${ }^{[54]}$ & 2010 & $\begin{array}{l}\text { Recurrence, renal } \\
\text { function }\end{array}$ & $\begin{array}{l}\text { RFA } \\
\text { PN }\end{array}$ & $\begin{array}{l}47 \\
42\end{array}$ & Retrospective & $\begin{array}{l}18 \\
30\end{array}$ & $\begin{array}{l}5 \text { recurrence } \\
3 \text { recurrence }\end{array}$ \\
\hline Stern et al.. ${ }^{[55]}$ & 2007 & $\begin{array}{l}\text { Recurrence, } \\
\text { complications }\end{array}$ & $\begin{array}{l}\text { RFA } \\
\text { PN }\end{array}$ & $\begin{array}{l}40 \\
37\end{array}$ & Retrospective & - & $\begin{array}{l}2 \text { recurrence, } 93.4 \% \text { (DFS) } \\
1 \text { recurrence, } 95.8 \% \text { (DFS) }\end{array}$ \\
\hline Sung et $a l^{[56]}$ & 2012 & $\begin{array}{l}\text { Recurrence, } \\
\text { complications, } \\
\text { renal function }\end{array}$ & $\begin{array}{l}\text { RFA } \\
\text { PN }\end{array}$ & $\begin{array}{l}40 \\
110\end{array}$ & Prospective & $\begin{array}{l}37 \\
37 \\
3 \text {-year }\end{array}$ & $\begin{array}{l}94.7 \%(\mathrm{RFS}) \\
98.9 \%(\mathrm{RFS})\end{array}$ \\
\hline Takaki et al. ${ }^{[57]}$ & 2010 & $\begin{array}{l}\text { Recurrence, } \\
\text { complications, } \\
\text { renal function }\end{array}$ & $\begin{array}{l}\text { RFA } \\
\text { PN } \\
\text { RN }\end{array}$ & $\begin{array}{l}51 \\
10\end{array}$ & Retrospective & $\begin{array}{l}34 \\
26 \\
40 \\
5 \text {-year }\end{array}$ & $\begin{array}{l}75.0 \%, 100 \%, 98.0 \% \\
(O S, R C C-r S, D F S) \\
100 \%, 100 \%, 75.0 \% \\
(O S, R C C-r S, D F S) \\
100 \%, 100 \%, 95.0 \% \\
(O S, \text { RCC-rS, DFS) }\end{array}$ \\
\hline
\end{tabular}

RFA: radiofrequency; PN: partial nephrectomy; RN: radical nephrectomy; OS: overall survival; CSS: cancer-specific survival; DFS: diseasefree survival; RFS: recurrence-free survival; RCC: renal cell carcinoma; RCC-rS: renal cell carcinoma-related survival

was found between LCA and PCA in renal function outcomes in the two largest comparative studies published so far ${ }^{[29-31]}$.

The reported overall rates of complications for CA procedures range from $7.8 \%$ to $20 \%{ }^{\left[{ }^{00]}\right.}$. The overall published complication rates for PCA $(7.8 \%-12.9 \%)$ were lower than the rates for LCA $(15 \%-20 \%)^{[30,32]}$. 
Table 2. Contemporary comparative series comparing cryoablation with different nephron sparing treatment options with oncological outcomes

\begin{tabular}{|c|c|c|c|c|c|c|c|}
\hline Author & Year & End point & Therapy & $\begin{array}{l}\text { Number of } \\
\text { patients }\end{array}$ & Study design & $\begin{array}{l}\text { Follow up } \\
\text { (months) }\end{array}$ & Outcomes \\
\hline Kim et $a /{ }^{[58]}$ & 2014 & $\begin{array}{l}\text { Survival, recurrence, } \\
\text { complications, renal } \\
\text { function }\end{array}$ & $\begin{array}{l}\text { PCA } \\
\text { LCA }\end{array}$ & $\begin{array}{l}118 \\
145\end{array}$ & $\begin{array}{l}\text { Prospective } \\
\text { evaluation }\end{array}$ & $\begin{array}{l}38 \\
71.4\end{array}$ & $\begin{array}{l}17 \%, 86.3 \%, 86.3 \% \\
(\mathrm{RR}, \text { OS, RFS) } \\
23 \%, 79.3 \%, 85.5 \% \\
(\mathrm{RR}, \mathrm{OS}, \mathrm{RFS})\end{array}$ \\
\hline El Dib et al. ${ }^{[59]}$ & 2012 & $\begin{array}{l}\text { Survival, recurrence, } \\
\text { complications }\end{array}$ & $\begin{array}{l}\text { CA } \\
\text { RFA }\end{array}$ & $\begin{array}{l}457 \\
426\end{array}$ & Retrospective & $\begin{array}{l}17.9 \\
18.1\end{array}$ & $\begin{array}{l}89 \% \text { CE } \\
90 \% \text { CE }\end{array}$ \\
\hline Atwell et al. ${ }^{[60]}$ & 2013 & $\begin{array}{l}\text { Survival, recurrence, } \\
\text { complications, }\end{array}$ & $\begin{array}{l}\text { PCA } \\
\text { RFA }\end{array}$ & $\begin{array}{l}163 \\
222\end{array}$ & Retrospective & $\begin{array}{l}1.8 \\
36 \text { (mean) }\end{array}$ & $\begin{array}{l}2.8 \%, 95.6 \% \text { (RR, RFS) } \\
3.2 \%, 97-2 \% \text { (RR, RFS) }\end{array}$ \\
\hline Tanagho et al. ${ }^{[6]]}$ & 2013 & $\begin{array}{l}\text { Survival, recurrence, } \\
\text { complications, renal } \\
\text { function }\end{array}$ & $\begin{array}{l}\text { LCA/PCA } \\
\text { RPN }\end{array}$ & $\begin{array}{l}267 \\
233\end{array}$ & Retrospective & $\begin{array}{l}39.8 \\
21.9\end{array}$ & $\begin{array}{l}12.7 \%, 83.1 \%, 96.4 \%, \\
77.1 \% \text { (RR, DFS, CSS, OS) } \\
0 \%, 100 \%, 100 \%, 91.7 \% \\
\text { (RR, DFS, CSS, OS) }\end{array}$ \\
\hline Guillotreau et al. ${ }^{[62]}$ & 2012 & $\begin{array}{l}\text { Survival, recurrence, } \\
\text { complications, renal } \\
\text { function }\end{array}$ & $\begin{array}{l}\text { RPN } \\
\text { LCA }\end{array}$ & $\begin{array}{l}210 \\
226\end{array}$ & Retrospective & $\begin{array}{l}4.8 \\
44.5 \text { (mean) }\end{array}$ & $\begin{array}{l}0 \%(R R) \\
11 \%(R R)\end{array}$ \\
\hline $\begin{array}{l}\text { Klatte et al. }{ }^{[63]} \\
\text { (meta-analysis) }\end{array}$ & 2014 & $\begin{array}{l}\text { Recurrence, } \\
\text { complications }\end{array}$ & $\begin{array}{l}\text { LCA } \\
\text { LPN/RPN }\end{array}$ & - & Retrospective & - & $\begin{array}{l}9.4 \% \text { vs. } 0.4 \% \\
\text { Metastasis } \\
4.4 \% \text { vs. } 0.4 \%\end{array}$ \\
\hline Thompson et al. ${ }^{[64]}$ & 2015 & $\begin{array}{l}\text { Survival, recurrence, } \\
\text { complications, } \\
\text { renal function }\end{array}$ & $\begin{array}{l}\text { CA } \\
\text { RFA } \\
\text { PN }\end{array}$ & $\begin{array}{l}187 \\
180 \\
1,057\end{array}$ & Retrospective & $\begin{array}{l}1.9 \\
3.6 \\
60\end{array}$ & $\begin{array}{l}3 \%, 98 \%, 100 \%, 88 \% \\
\text { (RR, RFS, MSF, OS) } \\
5 \%, 98 \%, 93 \%, 82 \% \\
\text { (RR, RFS, MSF, OS) } \\
36 \%, 98 \%, 99 \%, 95 \% \\
\text { (RR, RFS, MSF, OS) }\end{array}$ \\
\hline
\end{tabular}

RFA: radiofrequency; PN: partial nephrectomy; RN: radical nephrectomy; LCA: laparoscopic cryoablation; PCA: percutaneous cryoablation; RPN: robotic partial nephrectomy; LPN: laparoscopic partial nephrectomy; CE: cancer extirpation rate; RR: recurrence rate; OS: overall survival; CSS: cancer-specific survival; DFS: disease-free survival; MSF: metastasis-free survival; RFS: recurrence-free survival

RFA seems to be no different in Clavien complication rate in comparison to CA, however, Goel et al. ${ }^{[33]}$ founded a lower rate of complication for CA compared with RFA, probably because the freezing-induced injury is less destructive than heat-induced one ${ }^{[3,34]}$. Generally, the most common complications during the procedure or post-operative are bleeding and rupture of the iceball.

There is no consensus on the definition of recurrence after treatments for SRM and particularly after AT. Local recurrences mostly occur at the site of the primary treatment within the kidney. Conversely, extrarenal local recurrences are rare ${ }^{[35,36]}$. Today, most analyses have shown lower specific cancer mortality for PN compared to non-surgical treatments. In general, local recurrence rates after CA are higher than after surgery $(2 \%-11 \% \text { vs. } 1 \%-2 \%)^{[37,38]}$.

Ideally, histopathological confirmation and re-biopsy of previously treated lesions would improve data of recurrent or residual disease. Conversely, in the literature, the majority of reports relied on radiographic evidence of enhancement to define both residual and recurrent disease. PCA had a higher rate of residual disease/primary treatment failure in comparison to LCA: PCA residual disease seems to be more frequent and to occur earlier than LCA, even if the length of follow-up between groups is difference (approximately 14 months longer for LCA) ${ }^{[29]}$.

Zargar et al. ${ }^{[30]}$ found no significant difference in OS or RFS at 5 years between PCA and LCA. Conversely, in other studies seems that a lower rate of patients in the LCA group experienced a local recurrence as compared with the rate of PCA group ${ }^{[30]}$.

Factors that might have contributed to the differences in residual and recurrent disease between PCA and LCA are the size of the lesion, the anatomical location, and the probe size and number (in LCA tendency to use wider probes). 
To date, cost issues have not played a major role in driving decisions among treatment options. However, as health care expenses continue to rise, cost concerns are likely to play an ever-increasing role. Different studies have assessed cost, but their results differ based on some key postulated differences such as the period of observation, the definition of success and complication rates, different health-care systems, and also whether those with benign biopsies should be treated or followed up.

Chang et al. ${ }^{[39]}$ analyzed the cost-effectiveness of all NSS options for SRMs and concluded that for healthier younger patients (aged 65 years with a $<2 \mathrm{~cm}$ lesion or aged 75 years with a $3-4 \mathrm{~cm}$ lesion), immediate surgery represents the optimal NSS option with the best incremental cost-effectiveness ratio. Surveillance with possible delayed PCA was a cost-effective option for older patients or those with increased perioperative mortality risk. Observation represented the best strategy for patients who are poor surgical candidates and who had a life expectancy $<3$ year. It is worth noting that laparoscopic AT was not cost effective in any scenario regardless of age, comorbidities, and tumor size ${ }^{[39]}$. Bhan et al ${ }^{[40]}$, comparing RFA, CA, and observation for the treatment of SRMs, established that active surveillance with no initial biopsy and with subsequent PCA in case of disease progression was more cost-effective than immediate CA with or without biopsy and other observation options. They found that in terms of cost-effectiveness, all CA techniques were superior to RFA procedures owing to higher rates of retreatment for $\mathrm{RFA}^{[40]}$. Reporting direct comparative costs of LCA and PCA, LCA was significantly more expensive than PCA (3.5 times on average) ${ }^{[41]}$. However, these values need to be adjusted for patient and tumor characteristics to better gauge the cost incurred by each approach. Ideally, we have to consider also the cost of readmission, ongoing surveillance, and retreatment into the analysis.

Furthermore, Link et al. ${ }^{[42]}$ analyzed the cost-effectiveness of different treatment options, particularly comparative analysis between PCA and laparoscopic treatment options. The PCA was 2.2-2.7 times less costly than the other options and resulted in a cost savings of $\$ 3625$ to $\$ 5155$ per case. For Open PN, Laparoscopic PN, and LCA, the operative time and hospitalization accounted for $69 \%-91 \%$ of the cost. The Laparoscopic PN and LCA were cost advantageous over PCA only when more than five cryoprobes were used during the percutaneous procedure ${ }^{[42]}$.

\section{CONCLUSION}

AT seems to be a valid treatment option that could reduce complications and general impairment of classical surgical procedures. Finding the perfect candidate for AT is challenging due to the lack of objective criteria in the literature and of standardized techniques. Notably, the percutaneous approach seems to have lower complications rate than laparoscopic approach, especially in CA, and it can offer shorter hospital stay and faster recovery, which can be particularly appealing in an era of cost restriction in healthcare. Afterward, in the era of a multidisciplinary approach and tailored therapy, LCA could be a useful instrument to manage lesions for which PCA might have a failure or could be difficult and unfeasible. Hence, LCA should be collocated in a middle position for the management of SRM between PCA and NSS. Nevertheless, the application of this approach is dictated by the available technology and specific expertise of each center.

\section{DECLARATIONS}

\section{Authors' contributions}

Made contributions to conception and design of the study/review, performed data analysis and interpretation: Silvestri T, Celia A

Made substantial contributions to conception and design of the study/review, performed an entire revision of data analysis, re-interpretation and the revision for editors: Silvestri $\mathrm{T}$

Performed data acquisition: de Concilio B, Zeccolini G 


\section{Availability of data and materials}

Not applicable.

\section{Financial support and sponsorship}

None.

\section{Conflicts of interest}

All authors declared that there are no conflicts of interest.

\section{Ethical approval and consent to participate}

Not applicable.

\section{Consent for publication}

Not applicable.

\section{Copyright}

(c) The Author(s) 2019.

\section{REFERENCES}

1. Ljungberg B, Bensalah K, Canfield S, Dabestani S, Hofmann F, et al. EAU guidelines on renal cell carcinoma: 2014 update. Eur Urol 2015;67:913-24

2. Klatte T, Shariat SF, Remz M. Systematic review and meta-analysis of perioperative and oncologic outcomes of laparoscopic cryoablation versus laparoscopic partial nephrectomy for the treatment of small renal tumors. J Urol 2014;191:1209-17.

3. Schiffman M, Moshfegh A, Talenfeld A, Del Pizzo JJ. Laparoscopic renal cryoablation. Semin Intervent Radiol 2014;31:64-9.

4. Caputo PA, Ramirez D, Zargar H, Akca O, Andrade HS, et al. Laparoscopic cryoablation for renal cell carcinoma: 100-month oncologic outcomes. J Urol 2015;194:892-6.

5. Larcher A, Fossati N, Mistretta F, Lughezzani G, Lista G, et al. Long-term oncologic outcomes of laparoscopic renal cryoablation as primary treatment for small renal masses. Urol Oncol 2015;33:22.e1-9.

6. Johnson S, Pham KN, See W, Begun FP, Langenstroer P. Laparoscopic cryoablation for clinical stage T1 renal masses: long-term oncologic outcomes at the Medical College of Wisconsin. Urology 2014;84:613-8.

7. Guillotreau J, Haber GP, Autorino R, Miocinovic R, Hillyer S, et al. Robotic partial nephrectomy versus laparoscopic cryoablation for the small renal mass. Eur Urol 2012;61:899-904.

8. Long CJ, Kutikov A, Canter DJ, Egleston BL, Chen DY, et al. Percutaneous vs surgical cryoablation of the small renal mass: is efficacy compromised? BJU Int 2011;107:1376-80.

9. Aron M, Gill IS. Minimally invasive nephron-sparing surgery (MINSS) for renal tumours. Part II: probe ablative therapy. Eur Urol 2007;51:348-57.

10. Mahnken AH, Günther RW, Tacke J. Radiofrequency ablation of renal tumors. Eur Radiol 2004;14:1449-55.

11. Bandi G, Hedican SP, Nakada SY. Current practice patterns in the use of ablation technology for the management of small renal masses at academic centers in the United States. Urology 2008;71:113-7.

12. Campbell S, Uzzo RG, Allaf ME, Bass EB, Cadeddu JA, et al. Renal mass and localized renal cancer: AUA guideline. J Urol 2017;198:520-9.

13. Baust J, Gage AA, Ma H, Zhang CM. Minimally invasive cryosurgery--technological advances. Cryobiology 1997;34:373-84.

14. Gonder MJ, Soanes WA, Smith V. Experimental prostate cryosurgery. Invest Urol 1964;1:610-9.

15. Soanes WA, Gonder MJ, Shulman S. Apparatus and technique for cryosurgery of the prostate. J Urol 1966;96:508-11.

16. Hoffmann NE, Bischof JC. The cryobiology of cryosurgical injury. Urology 2002;60:40-9.

17. Stephenson RA, King DK, Rohr LR. Renal cryoablation in a canine model. Urology 1996;47:772-6.

18. Okhunov Z, Shapiro EY, Moreira DM, Lipsky MJ, Hillelsohn J, et al. R.E.N.A.L. nephrometry score accurately predicts complications following laparoscopic renal cryoablation. J Urol 2012;188:1796-800.

19. da Silva RD, Jaworski P, Gustafson D, Nogueira L, Kang F, et al. How I do it: laparoscopic renal cryoablation (LRC). Can J Urol 2014;21:7574-7.

20. Schmit GD, Atwell TD, Leibovich BC, Callstrom MR, Kurup AN, et al. Percutaneous cryoablation of anterior renal masses: technique, efficacy, and safety. Am J Roentgenol 2010;195:1418-22.

21. Zondervan PJ, Buijs M, de la Rosette JJ, van Delden O, van Lienden K, et al. Cryoablation of small kidney tumors. Int J Surg 2016;36:533-40.

22. Caputo PA, Zargar H, Ramirez D, Andrade HS, Akca O, et al. Cryoablation versus partial nephrectomy for clinical T1b renal tumors: a matched group comparative analysis. Eur Urol 2017;71:111-7.

23. Weld KJ, Figenshau RS, Venkatesh R, Bhayani SB, Ames CD, et al. Laparoscopic cryoablation for small renal masses: three-year follow-up. Urology 2007;69:448-51. 
24. Gill IS, Novick AC, Soble JJ, Sung GT, Remer EM, et al. Laparoscopic renal cryoablation: initial clinical series. Urology 1998;52:543-51.

25. Allen BC, Remer EM. Percutaneous cryoablation of renal tumors: patient selection, technique, and postprocedural imaging. Radiographics 2010;30:887-900.

26. Pan XW, Cui XM, Huang H, Huang Y, Li L, et al. Radiofrequency ablation versus partial nephrectomy for treatment of renal masses: a systematic review and meta-analysis. Kaohsiung J Med Sci 2015;31:649-58.

27. Olweny EO, Park SK, Tan YK, Best SL, Trimmer C, et al. Radiofrequency ablation versus partial nephrectomy in patients with solitary clinical T1a renal cell carcinoma: comparable oncologic outcomes at a minimum of 5 years of follow up. Eur Urol 2012;61:1156-61.

28. Johnson BA, Sorokin I, Cadeddu JA. Ten-year outcomes of renal tumor radio frequency ablation. J Urol 2019;201:251-8.

29. Pessoa RR, Autorino R, Laguna MP, Molina WR, Gustafson D, et al. Laparoscopic versus percutaneous cryoablation of small renal mass: systematic review and cumulative analysis of comparative studies. Clin Genitourin Cancer 2017;15:513-9.e5.

30. Zargar H, Atwell TD, Cadeddu JA, de la Rosette JJ, Janetschek G, et al. Cryoablation for small renal masses: selection criteria, complications, and functional and oncologic results. Eur Urol 2016;69:116-28.

31. Kim EH, Tanagho YS, Saad NE, Bhayani SB, Figenshau RS. Comparison of laparoscopic and percutaneous cryoablation for treatment of renal masses. Urology 2014;83:1081-7.

32. Atwell TD, Vlaminck JJ, Boorjian SA, Kurup AN, Callstrom MR, et al. Percutaneous cryoablation of stage T1b renal cell carcinoma: technique considerations, safety, and local tumor control. J Vasc Interv Radiol 2015;26:792-9.

33. Goel RK, Kaouk JH. Probe ablative treatment for small renal masses: cryoablation vs. radio frequency ablation. Curr Opin Urol 2008; $18: 467-73$.

34. Atwell TD, Schmit GD, Boorjian SA, Mandrekar J, Kurup AN, et al. Percutaneous ablation of renal masses measuring $3.0 \mathrm{~cm}$ and smaller: comparative local control and complications after radiofrequency ablation and cryoablation. AJR Am J Roentgenol 2013;200:461-6.

35. Adamy A, Chong KT, Chade D, Costaras J, Russo G, et al. Clinical characteristics and outcomes of patients with recurrence 5 years after nephrectomy for localized renal cell carcinoma. J Urol 2011;185:433-8.

36. Du Y, Grüllich C, Hadaschik B, Hatiboglu G, Hohenfellner M, et al. Local recurrence after curative surgical treatment of renal cell cancer: a study of 91 patients. Clin Genitourin 2016;14:e379-85.

37. Guillotreau J, Haber GP, Autorino R. Robotic partial nephrectomy versus laparoscopic cryoablation for the small renal mass. Eur Urol 2012;61:899-904.

38. Capogrosso P, Capitanio U, La Croce G, Nini A, Salonia A, et al. Follow-up after treatment for renal cell carcinoma: the evidence beyond the guidelines. Eur Urol Focus 2016;1:272-81.

39. Chang SL, Cipriano LE, Harshman LC, Garber AM, Chung BI. Cost-effectiveness analysis of nephron sparing options for the management of small renal masses. J Urol 2011;185:1591-7.

40. Bhan SN, Pautler SE, Shayegan B, Voss MD, Goeree RA, et al. Active surveillance, radiofrequency ablation, or cryoablation for the nonsurgical management of a small renal mass: a cost-utility analysis. Ann Surg Oncol 2013;20:3675-84.

41. Badwan K, Maxwell K, Venkatesh R, Figenshau RS, Brown D, et al. Comparison of laparoscopic and percutaneous cryoablation of renal tumors: a cost analysis. J Endourol 2008;22:1275-7.

42. Link RE, Permpongkosol S, Gupta A, Jarrett TW, Solomon SB, et al. Cost analysis of open, laparoscopic, and percutaneous treatment options for nephron-sparing surgery. J Endourol 2006;20:782-9.

43. Arnoux V, Descotes JL, Sengel C, Terrier N, Rambeaud JJ, et al. Perioperative outcomes and mid-term results of radiofrequency ablation and partial nephrectomy in indications of renal tumor treatment and imperative nephron-sparing procedure. Prog Urol 2013;23:99-104.

44. Bensalah K, Zeltser I, Tuncel A, Cadeddu J, Lotan Y. Evaluation of costs and morbidity associated with laparoscopic radiofrequency ablation and laparoscopic partial nephrectomy for treating small renal tumours. BJU Int 2008;101:467-71.

45. Bird VG, Carey RI, Ayyathurai R, Bird VY. Management of renal masses with laparoscopic-guided radiofrequency ablation versus laparoscopic partial nephrectomy. J Endourol 2009;23:81-8.

46. Chang X, Liu T, Zhang F, Ji C, Zhao X, et al. Radiofrequency ablation versus partial nephrectomy for clinical T1a renal-cell carcinoma: long-term clinical and oncologic outcomes based on a propensity score analysis. J Endourol 2015;29:518-25.

47. Chang X, Zhang F, Liu T, Ji C, Zhao X, et al. Radio frequency ablation versus partial nephrectomy for clinical T1b renal cell carcinoma: long-term clinical and oncologic outcomes. J Urol 2015;193:430-5.

48. Ji C, Zhao X, Zhang S, Liu G, Li X, et al. Laparoscopic radiofrequency ablation versus partial nephrectomy for cT1a renal tumors: long-term outcome of 179 patients. Urol Int 2016;96:345-53.

49. Kim SH, Lee ES, Kim HH, Kwak C, Ku JH, et al. A propensity-matched comparison of perioperative complications and of chronic kidney disease between robot-assisted laparoscopic partial nephrectomy and radiofrequency ablative therapy. Asian J Surg 2015;38:126-33.

50. Liu N, Huang D, Cheng X, Chong Y, Wang W, et al. Percutaneous radiofrequency ablation for renal cell carcinoma vs. partial nephrectomy: comparison of long-term oncologic outcomes in both clear cell and non-clear cell of the most common subtype. Urol Oncol 2017;35:530.e1-16

51. Lucas SM, Stern JM, Adibi M, Zeltser IS, Cadeddu JA, et al. Renal function outcomes in patients treated for renal masses smaller than $4 \mathrm{~cm}$ by ablative and extirpative techniques. J Urol 2008;179:75-80.

52. Olweny EO, Park SK, Tan YK, Best SL, Trimmer C, et al. Radiofrequency ablation versus partial nephrectomy in patients with solitary clinical T1a renal cell carcinoma: comparable oncologic outcomes at a minimum of 5 years of follow-up. Eur Urol 2012;61:1156-61.

53. Pantelidou M, Challacombe B, McGrath A, Brown M, Ilyas S, et al. Percutaneous radiofrequency ablation versus robotic-assisted partial nephrectomy for the treatment of small renal cell carcinoma. Cardiovasc Interv Radiol 2016;39:1595-603.

54. Raman JD, Raj GV, Lucas SM, Williams SK, Lauer EM, et al. Renal functional outcomes for tumours in a solitary kidney managed by ablative or extirpative techniques. BJU Int 2010;105:496-500. 
55. Stern JM, Svatek R, Park S, Hermann M, Lotan Y, et al. Intermediate comparison of partial nephrectomy and radiofrequency ablation for clinical T1a renal tumours. BJU Int 2007;100:287-90.

56. Sung HH, Park BK, Kim CK, Choi HY, Lee HM. Comparison of percutaneous radiofrequency ablation and open partial nephrectomy for the treatment of size- and location-matched renal masses. Int J Hyperthermia 2012;28:227-34.

57. Takaki H, Yamakado K, Soga N, Arima K, Nakatsuka A, et al. Midterm results of radiofrequency ablation versus nephrectomy for T1a renal cell carcinoma. Jpn J Radiol 2010;28:460-8

58. Kim EH, Tanagho YS, Saad NE, Bhayani SB, Figenshau RS. Comparison of laparoscopic and percutaneous cryoablation for treatment of renal masses. Urology 2014;83:1081-7.

59. El Dib R, Touma NJ, Kapoor A. Cryoablation vs radiofrequency ablation for the treatment of renal cell carcinoma: a meta-analysis of case series studies. BJU Int 2012;110:510-6.

60. Atwell TD, Schmit GD, Boorjian SA, Mandrekar J, Kurup AN, et al. Percutaneous ablation of renal masses measuring $3.0 \mathrm{~cm}$ and smaller: comparative local control and complications after radiofrequency ablation and cryoablation. AJR Am J Roentgenol 2013;200:461-6.

61. Tanagho YS, Bhayani SB, Kim EH, Figenshau RS. Renal cryoablation versus robot-assisted partial nephrectomy: Washington University long-term experience. J Endourol 2013;27:1477-86.

62. Guillotreau J, Haber GP, Autorino R, Miocinovic R, Hillyer S, et al. Robotic partial nephrectomy versus laparoscopic cryoablation for the small renal mass. Eur Urol 2012;61:899-904.

63. Klatte T, Shariat SF, Remzi M. Systematic review and meta-analysis of perioperative and oncologic outcomes of laparoscopic cryoablation versus laparoscopic partial nephrectomy for the treatment of small renal tumors. J Urol 2014;191:1209-17.

64. Thompson RH, Atwell T, Schmit G, Lohse CM, Kurup AN, et al. Comparison of partial nephrectomy and percutaneous ablation for cT1 renal masses. Eur Urol 2015;67:252-9. 